\title{
OPERATION GAZOPROAVLAUSIH WELLS THE FAR NORTH
}

\author{
- . устышев \\ D. A. Kustishev \\ «юмен гипрог з», г. юмень
}

лючевые слов : скв жин ; эксплу т ция г зопроявление; межколонное простр нство;

ф кельный отвод

Key words: well; operation; gas showing; annulus space; gas flare line

зовые и г зоконденс тные месторождения, н ходящиеся н территории

север п дной и осточной ибири, кутии и льнего осток , х р ктеризуются суровыми клим тическими условиями, бездорожьем и сл бой изученностью геологического строения з лежей. урение и эксплу т ция скв жин в этих условиях з труднены, эти процессы требуют к себе повышенного вним ния. ередко эти процессы связ ны с возникновением межколонных г зопроявлений. ксплу т ция скв жин с н личием межколонных д влений пр вил ми безоп сности з прещен без р зр ботки специ льных компенс ционных мероприятий, н пр вленных н обеспечение н дежности конструкций скв жин, их устьевых обвязок и н обеспечение повышенных мер пож рной и противофонт нной безоп сности $[1,2]$.

этих условиях необходим технология безоп сной эксплу т ции скв жин, имеющих межколонные д вления. езоп сность эксплу т ции, помимо н дежной 
конструкции с мой скв жины, т кже определяется н дежностью устьевых обвязок этих скв жин [3].

ще всего при эксплу т ции скв жин с межколонными г зопроявлениями применяется устьев я обвязк, н пример н полярном месторождении и ряде других месторождений $\mathrm{p}$ йнего евер, включ ющ я колонную головку с з движкой, перекрыв ющей межколонное простр нство, и дополнительный ф кельный отвод [4].

едост тком д нной обвязки является необходимость строительств т кого отвод , не предусмотренного проектно-сметной документ цией.

ногд используют устьевую обвязку, т кую к к H ов ненковском месторождении, включ ющую колонную головку с з движкой, перекрыв ющей межколонное простр нство, и дополнительный ф кельный отвод [5].

едост тк ми являются необходимость при ее ре лиз ции зн чительных к пит льных вложений, связ нных со строительством дополнительного ф кельного отвод, и невозможность в случ е необходимости 3 к ч ть в межколонное простр нство герметизирующую композицию для ликвид ции межколонных г зопроявлений.

ем не менее при использов нии этих обвязок реш ется основн я $з$ д ч эксплу т ция г зопроявляющих скв жин 3 счет возможности выпуск г 3 из межколонного простр нств и снижения величины межколонного д вления в скв жине.

дн ко при этом ост ется нерешенной друг я нем лов жн я з д ч - ликвид ция межколонных г зопроявлений путем 3 к чив ния в межколонное простр нство скв жины герметизирующей композиции. ля решения этой з д чи необходимо р зр бот ть новую схему обвязки г зопроявляющих скв жин, нез висимо от количеств секций колонных головок и числ межколонных простр нств.

нную $з$ д чу можно решить путем присоединения к к ждой $з$ движке, перекрыв ющей соответствующее межколонное простр нство скв жины, п трубков, p сположенных в горизонт льной плоскости, с р змещенным между ними соединительным п трубком, причем к верхнему угольнику присоединен дополнительн я межколонн я 3 движк , к которой прикреплен предохр нительный кл п н, к которому в свою очередь присоединен дополнительн я ф кельн я линия с концевой $з$ движкой, н торц х ф кельных линий р змещены горелки.

рисунке пок 3 н $\mathrm{p}$ зр бот нН я схем устьевой обвязки г зоконден тной скв жины с межколонными г зопроявлениями реднеботуобинского месторождения кутии, относящегося к месторождениям р йнего евер [6].

редл г ем я втором устьев я обвязк включ ет скв жину с устьем $1, \mathrm{p}$ сположенным в ш хтном колодце 2.

устье 1 р змещен многосекционн я колонн я головк 3 , к жд я секция которой сн бжен 3 движкой 4, перекрыв ющей соответствующее межколонное простр нство скв жины.

колонной головке 3 р змещен трубн я головк 5, сн бженн я н противоположных сторон х выкидным 6 и 3 д вочным 7 отвод ми. $\quad$ выкидном отводе 6 р змещены з трубные 3 движки 8 и 9, н 3 д вочном отводе 7 - 3 трубные 3 движки 10 и 11. ежду з движк ми 8 и 9 р змещен инструмент льный фл нец 12. трубной головке 5 р змещен фонт нн я елк тройникового тип, ствол которой выполнен из центр льной 13 и стволовой 14 д движек, р сположенных друг н д другом, нижнего 15 и верхнего 16 тройников и буферной з движки 17. верхнему тройнику 16 присоединен р боч я струн 18 с двумя струнными 3 движк ми 19, 20 и р сположенным между ними инструмент льным фл нцем 21. нижнему тройнику 15 присоединен резервн я струн 22 с двумя струнными 3 движк ми 23, 24 и р сположенным между ними инструмент льным фл нцем 25. 
боч я струн 18 с помощью тройник 26 соединен с выкидным отводом 6 трубной головки 5, обр зуя выкидную линию 27.

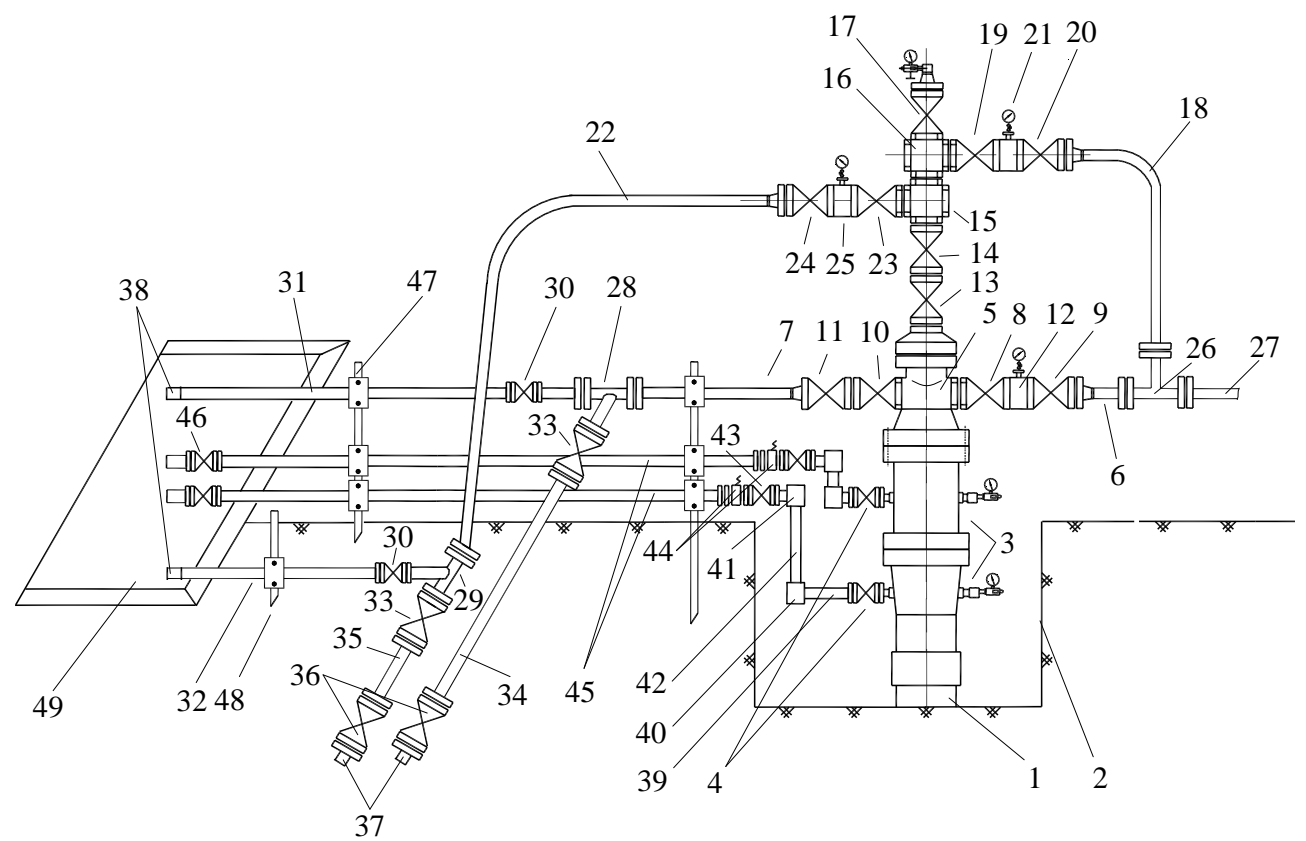

исунок. ринципи льн я схем устьевой обвязки г зоконденс тной скв жинь с межколонными г зопроявлениями

1 -устье; 2 - хт ; 3 -колонн я головк ; 4-з движк н межколонном простр нстве; 5 - трубн я головк ; 6-выкидной отвод; $7-3$ д вочный отвод; 8, 9, 10, 11 - з движк н з трубном простр нстве; 12,21,25-инструмент льный фл нец; 13 - центр льн яз движк;14-стволов я з движк ; 15 - нижний тройник; 16 - верхний тройник; 17 - буферн яз движк ; 18-р боч я струн ; 19, 20, 23, 24 струнн яз движк ; 26, 28, 29 - тройник; 27 - выкидн я линия; 30, 33 -отсек ющя я 3 движк; 31,32 - кельн ялиния; 34,35-3 д вочн ялиния; 37 - быстрор збемное соединение;38 - горелк ; 39,42 - п трубок; 40,41 - угольник; 43 - дополнительн я межкколонн яз движк ; 44 - предохр нительный кл $n$ н; 45 -дополнительн $я$ $\phi$ кельн ялиния; 46-концев яз движк; 47, 48-якорь; 49- мбр

концевых уч стк х резервной струны 22 и з д вочного отвод 7 трубной головки 5 р змещены тройники 28 и 29, к одному ответвлению которых через отсек ющую $з$ движку 30 присоединен ф кельн я линия 31 или 32, к другому, через отсек ющую з движку 33, з д вочн я линия 34 или 35, н торц х к ждой 3 д вочной линии 34 и 35 р змешены концевые отсек ющие 3 движки 36 с быстрор зъемными соединениями 37, н торц х ф кельных линий 31 и 32 - горелки 38.

к ждой 3 движке 4, р змещенной н колонной головке 3 и перекрыв ющей соответствующее межколонное простр нство скв жины, присоединен п трубок 39, p сположенный в горизонт льной плоскости, с угольник ми 40 и 41, р сположенными в вертик льной плоскости, с р змещенным между ними соединительным п трубком 42.

верхнему угольнику 41 присоединен дополнительн я межколонн я 3 движк 43, к которой присоединен предохр нительный кл п н 44, к которому в свою очередь присоединен дополнительн я ф кельн я линия 45 с концевой з движкой 46. ополнительные ф кельные линии 45 крепятся н якоре 47, н котором 3 креплен ф кельн я линия 31. кельн я линия 32 з креплен н якорях 48. 
процессе эксплу т ции г з из продуктивного пл ст по стволу фонт нной елки через открытые центр льную 13 и стволовую 14 з движки, по ее р бочей струне 18 и выкидной линии 27 поступ ет в г зосборный коллектор и д лее н уст новку комплексной подготовки г з (не пок з но).

ри появлении в процессе эксплу т ции межколонных г зопроявлений г 3 , ск плив ющийся в межколонном простр нстве скв жины, через открытые 3 движки 4, р змещенные в ш хтном колодце 2 скв жины, и 43, p змещенной н поверхности 3 предел ми ш хтного колодц 2, и через открывшийся предохр нительный кл п н 44, который открыв ется при превышении величины межколонного д вления выше н строечной величины кл п н , p вного предельно допустимой величине межколонного д вления д нной скв жины, поступ ет в дополнительную ф кельную линию 45 и выбр сыв ется в мб р 49, р сположенный в р йоне концевых уч стков ф кельных линий 31 и 32.

случ е в рийного увеличения р сход г з из межколонного простр нств скв жины через дополнительную ф кельную линию 45 можно 3 к ч ть в межколонное простр нство герметизирующую композицию для прекр щения г зопроявлений, подсоединив к концевой отсек ющей 3 движке 46 н сосную уст новку [7, 8, 9].

случ е невозможности ликвид ции межколонных г зопроявлений скв жину глуш т созд нием циркуляции з д вочной жидкости через 3 д вочную линию 35 , предв рительно перекрыв отсек ющую з движку 30 н ф кельной линии 32, и ф кельную линию 31, предв рительно перекрыв отсек ющую з движку 33 н 3 д вочной линии 34 [10].

зр бот нн я втором с учетом исследов ний . . енн , . . екетов , .

устышев по ди гностики скв жин с межколонными г зопроявлениями [11, $12,13]$ технология эксплу т ции г зопроявляющей скв жины с устьевой обвязкой позволяет провести обвязку межколонных простр нств г зоконденс тной скв жины с обеспечением безоп сного выпуск г з из межколонных простр нств скв жины с соблюдением безоп сности проведения р бот по 3 к чив нию герметизирущих композиций. омимо этого, он позволяет проводить циркуляцию з д вочной жидкости между трубным и з трубным простр нств ми при глушении скв жины по одному трубопроводу.

ким обр зом, р зр бот нные устьевые обвязки г зопроявляющих скв жин обеспечив ют возможность выпуск г з из их межколонных простр нств и сжиг ния его в обв лов нном мб ре, обеспечив ют возможность 3 к чив ния в межколонное простр нство герметизирующих композиций для ликвид ции межколонных г зопроявлений, т кже - созд ния циркуляции 3 д вочной жидкости между трубным и з трубным простр нств м с использов нием одного и того же трубопровод при глушении скв жин с межколонными г зопроявлениями.

\footnotetext{
писок литер туры

1. устышев . . ксплу т ция скв жин н месторождениях п дной ибири. - юмень: ектор ук, 2002. $-168 \mathrm{c}$.

2. ряквин . ., устышев . ., ейхм н . ., икифоров . . ксплу т ция скв жин н 3 верш ющей ст дии р зр ботки месторождений // звестия вузов. ефть и г з. - 2010. - № 4. - . 28-33.

3. устышев. ., г нов . ., ур влев. . ценк риск при ремонте нефтяных и г зовых скв жин // езоп сность труд в промышленности. - 2013. - № 9. - . 76-80.

4. т. 44143 . 21 43/25. стройство для эксплу т ции г зовых скв жин с межколонными г зопроявлениями / . . толь, . . у устышев, . . ыб лченко и др. ( ).- № 2004128574, 3 яв. 27.09.04; опубл. 27.02.05, бюл. № 6.

5. т. 111578 . 21 43/12. устов я обвязк г зовых скв жин с межколонными г зопроявлениями / . . емков, . . устышев, . . толь и др. ( ). - № 2011134831, 3 яв. 19.08.11; опубл. 20.12.11, бюл. № 35 .

6. т. $143089 \quad 21 \quad 43 / 25$. бвязк высокодебитной нефтег зоконденс тной скв жины с межколонными г зопроявлениями / . . устышев, . . озлов, . . устышев и др. ( ). - № 2014105118, з яв. 12.02.14; опубл. 10.07.14, бюл. № 19.
} 
7. оинс . . редотвр щение выбросов: ер. с нгл. / . . оинс, . еффилд. - .: едр , 1987. $-288 \mathrm{c}$

8. редотвр щение и ликвид ция г зопроявлений и открытых фонт нов при ремонте скв жин в экстрем льных условиях р йнего евер / . . б ев, . . устышев, . . озуля, . . ейхм н. - $\quad \therefore \quad$ зпром, 2007. -189 с.

9. борудов ние и инструмент для предупреждения и ликвид ции фонт нов: пр вочник / . . дковский, . . ымчук, . . енкевич, . . лохин. - .. едр , 1996. -376 с.

10. биднов . ., устышев . . лушение низкотемпер турных г зоконденс тных скв жин в условиях ном льно низких пл стовых д влений н месторождениях $\mathrm{p}$ йнего евер // звестия вузов. ефть и г 3. - 2014. - № 5. - . 33-39.

11. енн . . етоды ди гностики и ликвид ции межколонных флюидопроявлений при строительстве скв жин н месторождениях и : втореф. ...дис. к. т .н.: 05.15.10. - щищен 20.05.99. - т врополь, 1999. - 19 с.

12. екетов . . ехнология ди гностики герметичности з колонной крепи скв жин н месторождениях и подземных хр нилищ х г 3 // орный информ ционно- н литический бюллетень. - 2003. № $6 .-$. 38-42.

13. устышев . . ложные ремонты г зовых скв жин н месторождениях п дной ибири. $\therefore \quad$ « зпром экспо», 2010. $-212 \mathrm{c}$.

ведения об вторе

устышев енис лекс ндрович, К. ст рший н учный сотрудник гипрог 3», г. юмень, тел. 8(3452)286694, е-mail: denis1982k@mail.ru

\section{Information about the author}

Kustyshev D. A., Candidate of Science in Engineering, senior research worker of LLC «TyumenNIIgiprogas», phone: 8(3452)286694, e-mail: denis1982k@mail.ru 